\title{
Effect of Different Stocking Densities on Growth and Survival Rates of Sea Cucumber Holothuria scabra Seedlings
}

\author{
Abdul Malik Serang, Santi Penina Tua Rahantoknam, and Pitjont Tomatala
}

Fish Culture Technology, Tual State Fisheries Polytechnic, Maluku, Indonesia 97611

Email : amserang@gmail.com

\begin{abstract}
Abdul Malik Serang, Santi Penina Tua Rahantoknam, and Pitjont Tomatala. 2016. Effect of Different Stocking Densities on Growth and Survival Rates of Sea Cucumber Holothuria scabra Seedlings. Aquacultura Indonesiana, 17 (1): 30-34. As sea cucumber, Holothuria scabra is one of the fishery commodities which have high economic value, this species now is under overexploited. Sea cucumber aquaculture should be developed urgently. This research was conducted to evaluate the effects of stocking densities on the growth and survival rates of sea cucumber. This research was carried out by using pen culture with $5-9 \mathrm{~cm}$ in length or 30-50 g of seedlings. The sea cucumber was reared with stocking densities of 15 (treatment A), 20 (treatment B) and 25 individual $/ \mathrm{m}^{2}$ (treatment $\mathrm{C}$ ) in triplicates. The observation of growth and survival rates were done every two week. The water quality was measured every three day. The result indicated that the growth and survival rates was higher in treatment $\mathrm{A}$ than treatments $\mathrm{B}$ and $\mathrm{C}$.
\end{abstract}

Keywords : Density; Growth; Holothuria scabra

\section{Introduction}

Sea cucumber is being considered to be listed on Appendix II of CITES (Commission of International Trade on Endangered Species), which means sea cucumber will be restricted in international trade. Producer countries of sea cucumbers will be encouraged to have the rules of utilization, in order to maintain the sustainability of the species and the environment. In general, there are two alternatives as ways to control the production of sea cucumber, first with quota and second, to determine certain size that is allowed to be harvest, either way, Indonesia still needs big amount of sufficient data and information on sea cucumbers (Purwati, 2005).

Sea cucumbers is thorn-skinned animals species (Echinodermata) from Holothuriidae family. In Indonesia, in particularly in Southeast Maluku, there are several species of sea cucumber one of which is golden sandfish, Holothuria scabra (Yusron, 2001). Due to high economic value, this species is over-exploited and makes population of $H$. scabra has decreased in both the number and size. There is some worries about existence of $H$. scabra, which feared in next few years the population of sea cucumber type $H$. scabra could be extinct if the capture rate is greater than the rate of reproduction of sea cucumbers. Therefore, the sea cucumber aquaculture needs to be developed in order to maintain the sustainability of sea cucumber populations. In aquaculture, stocking densities is the crucial factor affecting the growth and survival rates. Higher stocking density increases the individual competition for space, feed and dissolved oxygen, whereas lower stocking density can lead to reduce the total production.

Research conducted by Chuanxin et al. (2009) indicated that the optimal stocking densities of sea cucumbers culture (with an initial body weight of $5 \mathrm{~g}$ individuals) were 22.3 individuals $/ \mathrm{m}^{2}$ and 14.1 individuals $/ \mathrm{m}^{2}$ under feed-supplement and non-feed-supplement regimes, respectively. Rukmini (2014) reported the research results of survival rate averaged the highest individuals on treatment 15 individuals $/ \mathrm{m}^{2} \quad(93.3 \%)$ and treatment 30 individuals $/ \mathrm{m}^{2}$ (91.1\%), the relative weight or the highest growth speed i.e $118.25 \%$ and $91.1 \%$. This study aimed to determine the density of sea cucumbers in order to get optimum growth and survival rate of sea cucumber $H$. scabra in order to improve the sustainability on sea cucumber aquaculture.

\section{Materials and Methods}

\section{Research Design}

This research was carried out on August until October 2013 in Ngilngof village using pen culture. Sea cucumbers with size of $5-9 \mathrm{~cm}$ in total length and $30-50 \mathrm{~g}$ of weight. The sea cucumbers were collected from the coastal 
around the area. Three stocking density treatments were used on this research, treatment A: density of 15 individuals $/ \mathrm{m}^{2}$, treatment B: density of 20 individuals $/ \mathrm{m}^{2}$ and treatment $\mathrm{C}$ : density of 25 individuals $/ \mathrm{m}^{2}$, in triplicates.

\section{Variables and Methods of Measurement}

The variables observed were the growth (length and weight) and the survival rate. Growth and survival rate were observed within an interval of two weeks. Length of body was measured by using calipers with accuracy rate at $0.1 \mathrm{~mm}$ while weight of the body weight was measured by using digital scales with accuracy rate at of $0.1 \mathrm{~g}$. Water qualities such as temperature, salinity, dissolved oxygen, $\mathrm{pH}$, nitrogen and phosphate were measured.

\section{Data Analyzes}

Data were analyzed to determine the absolute growth and daily growth rate. Absolute growth was calculated based the formula published previously (Effendie, 1997)

$$
L m=L t-L o
$$

Where :

$\mathrm{Lm} \quad$ : Absolute growth $(\mathrm{cm})$

Lt : The average length of the end of the research $(\mathrm{cm})$

Lo : The average weight of the beginning of the research $(\mathrm{cm})$

Daily growth rate was calculated based on the equation use by Bambang et al. (2011)

$$
G=\frac{L t-L o}{t}
$$

Where :

$\mathrm{G}$ : Daily growth rate

Lt : The growth of the test organisms at the end of the research $(\mathrm{g})$

Lo :The growth of the test organisms at the beginning of the research $(\mathrm{g})$

t $\quad$ : Rearing period (day)

Survival rate measured based on Effendie (1997) equation:

$$
\mathrm{S}=\frac{\mathrm{Nt}}{\text { No }} \mathrm{x} 100
$$

Where :

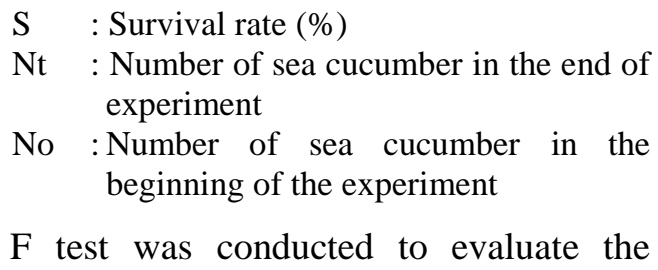
effect of the stocking density on growth and survival rates (Steel and Torrie, 1993).

\section{Results}

\section{Growth Rate}

The absolute and daily growth rates of sea cucumber during the experiment are showed in Table 1 and Table 2 .

Table 1. Growth of Length of sea cucumber at different stocking densities

\begin{tabular}{lcccccc}
\hline & \multicolumn{3}{c}{ Absolute Growth $(\mathbf{c m})$} & \multicolumn{3}{c}{ Daily Growth Rate (cm/day) } \\
\cline { 2 - 7 } & \multicolumn{3}{c}{ Treatment } & Treatment \\
\cline { 2 - 7 } & A & B & C & A & B & C \\
\hline Range & $0.44-0.56$ & $0.26-0.36$ & $0.23-0.437$ & $0.003-0.142$ & $0.003-0.021$ & $0.003-0.028$ \\
Average & 0.5 & 0.31 & 0.34 & 0.072 & 0.012 & 0.015 \\
\hline
\end{tabular}

Table 2. Growth of Weight of sea cucumber at different stocking densities

\begin{tabular}{lcccccc}
\hline & \multicolumn{3}{c}{ Absolute Growth (g) } & \multicolumn{3}{c}{ Daily Growth Rate (g/day) } \\
\cline { 2 - 7 } & \multicolumn{3}{c}{ Treatment } & \multicolumn{3}{c}{ Treatment } \\
\cline { 2 - 7 } & A & B & C & A & B & C \\
\hline Range & $11.13-12.26$ & $7.5-8.05$ & $3.06-4.96$ & $0.142-0.607$ & $0.107-0.464$ & $0.035-0.392$ \\
Average & 11.695 & 7.78 & 4.01 & 0.374 & 0.285 & 0.213 \\
\hline
\end{tabular}


Results indicated that the stocking densities significantly affected the absolute growth of length and weight $(P<0.05)$. The highest absolute growth of length was obtained by $\mathrm{A}$ treatment, followed by $\mathrm{C}$ treatment, and $\mathrm{B}$ treatment. The highest absolute growth of weight was obtained by A treatment followed by B treatment and $\mathrm{C}$ treatment.

\section{Survival Rate}

The survival rate of sea cucumbers during experiment is showed in Figure 1.

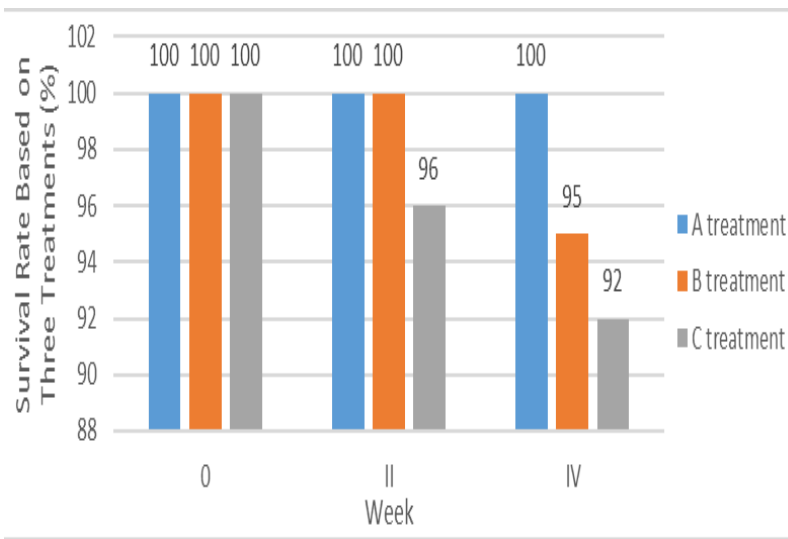

Figure 1. Survival rate of sea cucumber during experiment

\section{Water Quality}

The water quality parameters during the

study are showed in Table 3 .

Table 3. Water quality parameter during experiment

\begin{tabular}{clc}
\hline No & \multicolumn{1}{c}{ Parameters } & Range \\
\hline 1 & The temperature $\left({ }^{\circ} \mathrm{C}\right)$ & $28-29$ \\
2 & Salinity $(\mathrm{ppt})$ & $31-33$ \\
3 & $\mathrm{pH}$ & $6.9-8.02$ \\
4 & Dissolved Oxygen $(\mathrm{mg} / \mathrm{L})$ & $6.83-8.40$ \\
5 & Nitric $(\mathrm{mg} / \mathrm{L})$ & 0.008 \\
6 & Nitrate $(\mathrm{mg} / \mathrm{L})$ & $<5$ \\
7 & Fosphate $(\mathrm{mg} / \mathrm{L})$ & $<0.25$ \\
\hline
\end{tabular}

\section{Discussion}

Growth is change of the length or weight of an organism in a given time period. Table 1 and Table 2 showed seedling of $H$. scabra with different stocking densities and without feeding. The sea cucumber grew either in length or body weight, indicated that the sea cucumber got enough intake of foods that naturally be transported by sea current. Micro-organisms such as bacteria and protozoa, benthos, macro-algae and detritus are the natural food of sea cucumbers (Anonymous, 2008). This natural food is essentially needed by sea cucumbers for growth.

Table 1 and Table 2 show the average absolute growth of weight reaching $4.01-11.695$ $\mathrm{g}$ while the average absolute growth in length were $0.31-0.5 \mathrm{~cm}$. This indicated that the average absolute growth of weight of sea cucumbers was more significant than the average absolute growth of length. Susilowati et al. (2004) reported that body weight growth of sea cucumber is faster than its body length growth.

Table 1 and Table 2 show that the absolute body length and absolute body length weight growths were highest in A treatment ranging from 11.13 to 12.26 , followed by $\mathrm{B}$ and $\mathrm{C}$ treatments. The highest daily growth rate was also obtained by A treatment due to low competition for feed. Feed is an external factor that had the most prominent effect on the growth of organisms. The limited available feed and the high stocking density cause the sea cucumber has lower chance to find enough feed. Effendie (1997) reported the growth rate of organism is highly determined by the availability of feed.

Cholik et al. (2005) stated that sea cucumber in the body weight range of $40-60 \mathrm{~g}$ should be reared at the stocking density of 6-8 individuals $/ \mathrm{m}^{2}$. While Yaqing et al. (2004) suggested the amount of sea cucumber juvenile released is $15-40$ individuals $/ \mathrm{m}^{2}$ for individuals measuring $2-5 \mathrm{~cm}, 15-25$ individuals $/ \mathrm{m}^{2}$ for individuals of $5-10 \mathrm{~cm}$, and $5-8$ individuals $/ \mathrm{m}^{2}$ when they are $10-15 \mathrm{~cm}$ in length.

Stocking density on the cultivation of cucumbers should be based on the size of the seedling and food availability in the area of cultivation. Sea cucumber seedling in the size of 20-30 g should be reared at the stocking density of $15-20$ individual $/ \mathrm{m}^{2}$, while in the size of $40-50$ $\mathrm{g}$ shoul be reared at the stocking density of 10-15 indivudual $/ \mathrm{m}^{2}$ (Rustam, 2006). Susilowati et al. (2004) reported that the stocking density influences the weight gain of sea cucumbers, but it does not affect the absolute growth of length. Stocking density at 10 individual $/ \mathrm{m}^{2}$ is better than that of 15 individual $/ \mathrm{m}^{2}$ in the term of weight gain.

Figure 1 shows the survival rate of sea cucumbers during this study. At the end of the treatment period, the highest survival was found in A treatment (100\%) followed by B (95\%) and $\mathrm{C}$ treatments $(92 \%)$. The highest survival rate was obtained by A treatment due to the low 
stocking density and enough availability of feed in the area. The feeding and space competitions cause the sea cucumbers in the $\mathrm{B}$ and $\mathrm{C}$ treatments have lower survive rate. Behavior observation of the sea cucumber indicated that their activities decreased in the two last treatment because of the lack of food supply that was found especially in the end of experiment.

Water quality is a very important factor in sea cucumber culture. Temperature is an important factor for the life of marine organisms as temperature affects directly or indirectly to organisms physiology. Hendri et al. (2009) explained that sea cucumber species $H$. scabra live and breed well in an aquatic environment at temperature of $27-30^{\circ} \mathrm{C}$. Table 3 shows that the water temperatures at the study site were in the range of $28^{\circ} \mathrm{C}-29^{\circ} \mathrm{C}$. The result indicated that the temperature range was in the optimum range for growth of $H$. scabra seedling.

Salinity is an important factor relating to the distribution and cultivation of cucumbers. Martoyo et al. (2006) suggested that the optimal water salinity for sea cucumbers ranged between 28-32 ppt. During this study, salinity ranged in the optimum salinity of 31-33 ppt. This indicates that there is no sudden change in salinity and the observation result indicated the optimum salinity range to support the activities of $H$. scabra sea cucumber seedlings.

The potential of hydrogen $(\mathrm{pH})$ affects productivity of aquatic area which can also affect the growth of aquatic organisms. Alkaline and neutral water area tend to be more productive than the acidic water where lives of aquatic creatures will be disrupted when the $\mathrm{pH}$ on the water is differ from the normal point $(\mathrm{pH} 7)$. Rustam (2006) asserted that the eligible $\mathrm{pH}$ for life-pearl range from 6.9 to 8.5 . Results of $\mathrm{pH}$ measurement during the study ranged from 6.9 to 8.02 indicated that water $\mathrm{pH}$ in this study area supported the survival and growth of $H$. scabra seedlings.

Dissolved oxygen (DO) is a barrier factor for life of marine biota. Aquatic biota including sea cucumbers live in a normal state when the oxygen is available sufficiently in the water. Dissolved oxygen in water is affected by the temperature where the dissolved oxygen is inversely proportional with temperature. Purcell et al. (2006) stated that the optimum dissolved oxygen for growth and survival of sea cucumbers is above $5 \mathrm{mg} / \mathrm{L}$. This means that the dissolved oxygen during culture (6.83 to $8.40 \mathrm{mg} / \mathrm{L})$ support the survival and growth of $H$. scabra.
Nitrogen and phosphate are determinant factor of fertility of water. Nitrogen and phosphate concentrations in this study indicated that nitrogen content on the area of study was $<5$ $\mathrm{mg} / \mathrm{L}$ and phosphate was $<2.5 \mathrm{mg} / \mathrm{L}$. Susilowati et al. (2004) explained that the level of nitrogen and phosphate for the growth of sea cucumber is $<5$. Thus nitrogen and phosphate concentrations in this study were suitable for the growth of sea cucumbers.

Based on the results and discussion above, we conclude that the growth and survival rate of sea cucumber with stocking density of 15 individuals $/ \mathrm{m}^{2}$ is better than the sea cucumber with stocking density of 20 individuals $/ \mathrm{m}^{2}$ and 25 individuals $/ \mathrm{m}^{2}$.

\section{Acknowledgement}

My thanks for the Minister of Research Technology and Higher Education for funding this research through competitive research grants scheme as well as the Director of Tual State Fisheries Polytechnic.

\section{References}

Anonymous. 2008. Prospek pembenihan dan budidaya pembesaran teripang metode kurungan tancap. InfoMAI, $17: 23$ - 29.

Bambang, S., I. Rusdi, S. Ismidan, dan R. Rahmawati. 2011. Pemeliharaan yuwana abalon (Haliotis squamata) Turunan F-1 secara terkontrol dengan jenis pakan berbeda. Jurnal Riset Akuakultur. 5 :199-209.

Effendie, M.I. 1997. Biologi perikanan. Yayasan Pustaka Nusantara. Yogyakarta. 161 p.

Cholik, F., A.G. Jagatraya., R.P. Poernomo, dan A. Jauzi. 2005. Akuakultur tumpuan harapan masa depan bangsa. Penerbit Masyarakat Perikanan Nusantara dan Taman Akuarium Air Tawar. Taman Mini Indonesia Indah. Jakarta. 378 p.

Chuanxin, Q., D. Shuanglin, T. Fuyi, T. Xiangli, W. Fang, D. Yunwei, and G. Qinfeng. 2009. Optimization of stocking density for the sea cucumber, Apostichopus japonicus Selenka,under feed-supplement ang nonfeed-supplement regimes in pond culture. Jurnal Ocean University China, 8 (3): 296302.

Hendri, M., A.I. Sunaryo, dan R.Y. Pahlevi. 2009. Tingkat kelulusan hidup larva teripang pasir (Holothuria scabra, Jaeger) dengan perlakukan pemberian pakan alami berbeda di Balai Besar Pengembangan Budidaya Laut (BBPBL) Lampung. Jurnal Penelitian Sains, 12 1(D) : 12110-1-12110-5. 
Martoyo, J., N. Aji, dan T. Winanto. 2006. Budidaya teripang, Cet. 6, edisi revisi. Penebar Swadaya. Jakarta. 69 p.

Purcell. S.N., F.B. Bernard, and N.N.S. Agudo. 2006. Transportation methods for restocking of juvenile include sea cucumber, Holothuria scabra. Aquaculture, 251:238 - 244.

Purwati, P. 2005. Sea cucumber Indonesia: The composition of the type and the history of the fishery. Oseana, XXX : $11-18$.

Rukmini. 2014. The different variations stocking density for culturing sea cucumbers (Holothuria scabra Jeager) step on the sand using a net system. In: Proceeding of International and National Conference on Marine Science and Fisheries, Agustus 2014, Makassar, Sulawesi Selatan: 208-212.

Rustam. 2006. Aquaculture training (Coremap phase II districts of a screen of aquaculture) sea cucumber Mattirotasi Foundation. Makassar. $11 \mathrm{p}$.

Susilowati, T., E. Arini dan D. Rachmawati. 2004. Budidaya teripang/ketimun laut
(Holothuria sp.) di perairan Karimunjawa. Laporan penelitian. Universitas Diponogoro. $42 \mathrm{p}$.

Steel, R.G.D. and J.H. Torrie. 1993. The principles and procedures of statistics: a biometric approach. The second edition. PT. Gramedia Pustaka Utama. Jakarta. 772 p.

Yaqing, C., Y. Changqing, and Songxin. 2004. Pond culture of Sea cucumbers, Apostichopus japonicus, in Dalian. In: A Lovatelli, C. Conand, S. Purcell, S. Uthicke, J-F. Hamel \& A. Mercier (eds), Advances in Sea Cucumber Aquaculture and Management, pp. 269-272. FAO Fisheries Technical Paper No 463. FAO, Rome.

Yusron, E. 2001. Studi perikanan teripang (Holothuroidea) di kabupaten Tual Maluku Tenggara. Jurnal Pesisir dan Pantai Indonesia. VI. ISBN 979-8105-83-4 (jil. 6) Pusat Penelitian dan Pengembangan Oseanologi LIPI. Jakarta. 